\title{
Effect of chromium supplementation with rehabilitation exercises on the restoration of functional efficiency of the posterior femoral muscles with partial muscular rupture "Dr/ Mostafa Ibrahem Ahmed Ali
}

\section{Research Introduction:}

With the increasing popularity of competitive sports and the high level of sports achievement, the probability of sports injury of all types and severity of the degree of athlete increases, especially with the high intensity of competition and training loads and the presence of constant pressure during sports competition (7:2).

Injury is one of the main obstacles that lead to the decline of the player's physical and skill level, hindering the player from continuing training and may cause him, even after the completion of recovery, lack of performance and incomplete skill, and reduce the level of skill performance due to lack of training for long periods. (10:15)

The femoral biceps are susceptible to injury in the running stage at extreme speed, as well as when doing excessive tidal action as well as when the ball is passed or straightened, and occurs to players who lack flexibility in the torso, as a result of a direct blow from the opponent. (8: 63)

This is consistent with Mervat al-Sayyid (1998) that the athletes most susceptible to tears are the anterior and posterior muscles of the thigh. (14: 89)

The posterior thigh muscle is an important muscle in the body for exercise, and its injury limits the athlete's ability to perform and may not be able to continue his exercise. A tear can be torn if it is stretched longer than its resting length by more than $25 \%$, and tear usually occurs at the weakest point of the muscle, and the most torn muscle is the posterior femoral muscle and anterior thigh muscle. (1: 316321)

Rupture of the muscle may occur at the origin or

Assistant Professor of Sports Injury- Faculty of Physical Education -Assiut University. 
indigestion and can occur in the middle of the muscle in the interior or one of the limbs, but often note most of the rupture injuries are in the area near the muscle or origin where the degree of elasticity of fibers of these parts less than the center of the muscle.

The injury may be as simple as the rupture of the outer envelope of the muscle in one part or partial rupture of some fibers or a total rupture of the muscle or tendon.According to the changes associated with the injury and the amount of blood bleeding and internal spills that determine the size of the tumor and the degree of pain in this case is called partial rupture. (13: 180-182)

It should be borne in mind that being away from the stadium, not participating and doing the athlete's efforts to do because of injury leads to weakness and deterioration in muscle efficiency in muscles and is usually a program to reduce the rapid loss of muscle strength. (4: 115)

The rehabilitation phase after injury is one of the most important stages in the treatment of sports injuries, which determine the player's return to the stadium and compete, and the process of rehabilitation after injury aims to return the player to the stadium as soon as possible while maintaining the physical and skill level of the player who was before the injury. : 162)

One of the most important therapeutic methods used are rehabilitative exercises, which is a codified movements based on scientific physiological and anatomical bases and described by this name in order to restore the body to its natural state or to the state of the previous nature. 9: 84

This has increased the interest in rehabilitation exercises, which play a major role in the lives of the injured by strengthening their muscles and improve the flexibility of the joints and raise the physical and technical efficiency to be qualified to endure physical work and maintain the balance of the body and to develop muscle strength and joint flexibility and the degree of neuromuscular compatibility to restore functional efficiency. Give physical therapeutic 
exercises and sports medical rehabilitation to sports injuries after the end of the acute period of pain.

Irvin \& Roy (1993) also stresses that therapeutic exercises are the main focus in the treatment of injuries because they aim to remove the dysfunction of the injured part by strengthening muscles, ligaments and joints and attention to the mechanics of the body movements and proper strength through rehabilitation programs and therapeutic exercises. On the development and development of muscle strength and articular flexibility and the degree of neuromuscular compatibility and restore the injured individual's normal state of the balance of the body and perform the duties of his life to the fullest, and some medical schools rely on rehabilitation exercises entirely in the treatment of injuries $\mathrm{d} \mathrm{N}$ the intervention of any other factors, such as treatment of drug injection and refractories only in the case if necessary and take care of the modern guidelines need to start treatment program after the injury period not more than 48 hours if the doctor recommended otherwise. (28) However, a large number of biologically active substances, including minerals, may have direct, primary or secondary effects on the immune system and are of interest to pathologists, immunologists and toxicologists. Different minerals are responsible for many biochemical, immunological and physiological activities of the body as micronutrients. Some of them lead to disorders of immune system function, leading to increased susceptibility to infection, and a variety of hypersensitivity reactions, autoimmune diseases and tumors.Metals are of great importance in altering the immune response by mechanisms of immune stimulation or immunosuppression.

Chromium is a metallic element (symbol $\mathrm{Cr}$, atomic number 24), which uses oral chromium supplement and injections as a food supplement, and has received a great deal of attention because of its potential beneficial effects on muscle strength and 
body composition, a dietary supplement widely used for its optimal function in sensitivity Insulin, is used by patients to promote weight loss and to increase lean body mass. (16) Chromium enters the body in other ways, such as the lungs and gastrointestinal tract and, to a lesser extent, through the skin. Inhalation is the most commonly used method. Exposure comes by eating food and water containing chromium, regardless of the exposure method. Chromium absorption is poorer by mouth, and therefore is not Chromium may be very toxic when administered orally, but chromium may cause damage by skin and inhalation methods and cause lung cancer, irritation and ulcer of the nose, hypersensitivity reactions and dermatitis. The main ways of secreting chromium are through the kidneys / urine and bile / feces. (31) (23)

Hoffman et al. (2014) 21 suggest that chromium availability positively affects carbohydrate and lipid metabolism as well as GLUT-4 transport. Furthermore, chromium appears to increase insulin response.
Injuries in the game of football are frequent and frequent, most of which is the injury of the biceps femoris (posterior muscle), which results in rupture of the envelope sac of the muscle or partial rupture or total rupture and in order to restore the functional efficiency of the muscle to its normal state must pass the rehabilitation of the injured muscle For normal work, which must be built on sound scientific principles through the use of rehabilitation exercises that work to strengthen and restore flexibility and elasticity of the affected muscle.

From the previous presentation and through the work of the researcher in the field of rehabilitation of sports injuries, and through contact with other teams in the games, the researcher noted the complaint of many players of the inability to return the same functional efficiency after injury, prompting the researcher to try to use chromium supplement with rehabilitation exercises to restore efficiency Posterior hip muscles with partial rupture, depending on the intake of chromium supplement used to 
help speed up the player's return and restore efficiency in the shortest possible time in order to avoid complications and health, psychological and physical problems that may be exposed to the player As a result of his injury.

Research aim :

The aim of this research is to determine the effect of chromium supplementation with rehabilitation exercises on the restoration of functional efficiency, through: - Fast cure and ease the degree of pain to the biceps femoral muscles after a partial muscle rupture.

- Restoring muscle strength to the posterior femoral muscles after a partial rupture.

\section{Research Hypotheses:}

1. There are statistically significant differences between the mean scores of the pre- and post-measurements of the subjects in the study in the degree of pain of the posterior femoral muscles after a partial muscle rupture and in favor of the scores averages telemetry.

2. There are statistically significant differences between the mean scores of the pre- and post-measurements of the sample members under consideration in the muscular strength of the posterior femoral muscles after they have partial muscle rupture and in favor of the averages of post-scales.

\section{Previous}

studies:

\section{First: Arabic Studies}

1- "Ashraf El-Desouky Shaalan" (2004) (5): "Building a test to measure the efficiency of the posterior thigh muscles after healing of cramp". The researcher used a descriptive (analytical) method and the data collection tools were a questionnaire to build the test, its axes, scores and some tools to apply the test. Extraction of a test to measure the efficiency of the posterior thigh muscles after healing muscle tears to its degrees.

2- The study of "Ahmed Abdel Aziz Abdel Nasser" (2010) (2): entitled "The effect of a proposed rehabilitation program on the structural structure of the muscles of the biceps femoralmuscle cramp" The research aims to identify the effect of using the proposed rehabilitation program and electrical stimulation and muscle lengthening using PNF method On the structural structure of 
posterior femoral muscles with torn muscle of the second degree. Use the CA alarm In addition, the application of the proposed rehabilitation program has a positive effect on the development and increase of both (back muscle strength - elastic muscles of the back - thigh circumference the speed of healing muscle rupture through the procedure of ultrasound).

Search

procedures:

Research Methodology:

The researcher used the experimental method to suit the nature of the research according to the nature of the research and its objectives on one experimental group using the experimental design of pre and post measurement.

\section{research community}

The research community included football players with partial tear in the biceps femoral muscles and enrolled in the Egyptian Football Association sports season 2017 from various clubs in the governorate of Assiut.

The research sample :

(18 football players) was selected from with partial tear in the biceps femoral muscles in the deliberate manner and enrolled in the Egyptian Football Association (third degree) sports season 2017 from clubs in the province of Assiut.

\section{Table (1)}

Moderation of the sample in the basic variables (under consideration) $(\mathrm{N}=9)$

\begin{tabular}{l|c|c|c|c|c}
\hline \hline \multirow{2}{*}{ Variables } & \multicolumn{2}{|c|}{$\begin{array}{c}\text { Experimental } \\
\text { group }\end{array}$} & \multicolumn{2}{c|}{ Control group } & \multirow{2}{*}{ Test t } \\
\cline { 2 - 5 } & $\begin{array}{l}\text { Standard } \\
\text { deviation }\end{array}$ & Average & Average & $\begin{array}{c}\text { Standard } \\
\text { deviation }\end{array}$ & \\
\hline \hline Age / year & 1.731 & 24.00 & 23.00 & 1.451 & 1.177 \\
\hline $\begin{array}{l}\text { Pain degree / } \\
\text { degree }\end{array}$ & 9.21 & 92 & 89 & 8.41 & 0.927 \\
\hline $\begin{array}{l}\text { Period of } \\
\text { injury / day }\end{array}$ & 0.243 & 8 & 7 & 0.147 & 0.345 \\
\hline \hline
\end{tabular}

Table T value (2.26) at the significance level (0.05)

Research Areas:

Timeline: Implemented from 8

July to 11 August 2017 
Human field: (10) were selected football players with partial tear in the biceps femoral muscles and enrolled in the Egyptian Football Federation (third class) sports season 2017 from the clubs of the province of Assiut (Assiut Petroleum - Manfalut - Badari Assiut Cement - Abu Tig Young Asyut)

\section{Data Collection Tools}

1. Reference survey through access to references and previous studies and some scientific journals specialized in the field of research. 2. Personal interview with experts and specialists in the field of sports injury, rehabilitation and nutrition of athletes and therapeutic nutrition.

3. Personal data form and diagnosis designed by the researcher. Attachment

4. Measurements Form (Muscle Strength) Attachment (3)

5. Expert Questionnaire on the proposed program for partial cervical rupture of the injured posterior femoral muscles. The questionnaire will be presented to a group of professors. Attachment (Physical Medicine and
Orthopedics - Health Sciences Specialty Injuries and Sports Rehabilitation).

6 . Visual symmetry to measure the degree of pain (VAS). Facility

7. Dynamometer to measure muscle strength of the thigh muscles. Facility (4)

\section{Rehabilitation Exercises (Under Research) Annex (1) The goal of the qualifying exercises:}

Rehabilitation exercises aim to reduce the degree of pain and restore muscle strength using chromium supplement with rehabilitation exercises and reach the range of motor to the normal state or as close to the normal state.

Basics of building and implementing rehabilitation exercises:

The researcher has taken into account the following principles in the implementation of rehabilitation exercises: 1. Rehabilitation exercises shall be carried out individually according to the condition of each casualty. 2. Graduation of pregnancy commensurate with the rehabilitation stage and the condition of each injured. 
3. Take into account the individual differences of the injured and to carry out exercises within the limits of pain for each patient. 4. The injured person should perform the exercises given in each rehabilitation session again on the same day in the evening (ie once in the morning and once in the evening), such as daily at home, after teaching the injured person and one of his companion ways to carry out these exercises and the time and performance of each exercise.

5. Taking into account that the proposed exercises are in line with the general or main objective of the program and the appropriate training exercises for the sample in question.

6. Flexibility of rehabilitation exercises, their applicability to practice, and their adaptability, without prejudice to the general principles of rehabilitation.

7. The total time to carry out the rehabilitation exercises 4 weeks.

8. Rehabilitation exercises were carried out during a 4week period (total program time) at 3 weekly sessions. 9. Exercise time within the rehabilitation unit ranged from $15: 45 \mathrm{~s}$ according to the condition of each injured person.

The content of the qualifying exercises:

Start with exercises to relieve pain and even get rid of it, and develop the muscle tone of the hip.

B) Performing a set of positive rehabilitation exercises so that the injured person performs the exercises without assistance, taking into account the individual differences of each casualty on the degree of injury.

C) Exercise with the same performance with the load gradient, then given resistance exercises to reach the maximum possible range of movement closer to normal.

Methods of Evaluation of Qualifying Exercises:

1- The researcher used visual analogy to determine the degree of pain in the pre and post measurements to determine the extent of improvement.

2- 2 - The researcher used dynamometer to measure muscle strength in the pre and 
post measurements to determine the extent of improvement.

3- Ration of chromium dose:

Through a review of professors specialized in the field of nutrition and drugs, Faculty of Medicine, Assiut University, as well as reference to studies on the use of nutritional supplement chromium, including the study "Walker et al. Walker et, al," (1998) (32), and the study "Gilbert et al." al, (1998) (19), the study of Melvin (2005), 25 and the study of Henry et al. (2007). 20 The safe chromium supplement dose of 200 micrograms has been prescribed. Daily capsule / day for 4 weeks after an hour meal to help protein synthesis, maintain blood sugar and increase insulin sensitivity Eating causes an increase in the activity of the thyroid gland, causing the burning of fat, was used "chromax chromium picolinate $200 \mathrm{mcg}$ product."

Scouting Experience:

The

researcher

conducted a pilot study in the period (6: 20 July 2017) on a sample of the original community and within the core research sample of 3 players with partial rupture or tension of the third degree in the biceps femoral muscles taking into account the equivalence of the members of the survey sample and match the specifications and conditions selected On the conditions that were applied to the basic sample.

- The study aimed to:

- Preparation of the registration form of data and measurements for each injured player and methods of carrying out rehabilitation exercises to suit the nature of the injury. - Ensure the safety of tools and devices used.

- Access to the most appropriate conditions for the injured during the performance of rehabilitation exercises - Identify the extent of the injured response to the method of exercise used.

- Determine the appropriate content of the proposed exercise program to be used. - Estimate the appropriate time for each rehabilitation unit. - Determine the most appropriate intervals between the various exercises and rehabilitation units. - Identify the difficulties that 
the researcher may face during the basic experiment and try to overcome them.

- Identify the appropriate dose of chromium supplement to assist in the rehabilitation process.

The results of the pilot study resulted in:

- Appropriate rehabilitation exercises used and the availability and accuracy of the results and understand the injured to the nature and importance of use.

- The availability of measuring instruments, tools and playgrounds for the implementation of rehabilitation exercises.

- The researcher's understanding of the nature of the injury and how to deal with it.

- Taking the opinion of the doctor in determining the beginning of the application of the rehabilitation program (under research).

- Choose the most appropriate times to start the patient with exercises taking into account the individual formula when performing exercises.

- Suitable testing, availability and accuracy of the results and understand the injured for the nature and importance of its use.

- The researcher's understanding of the nature of the injury and how to deal with it.

- Determine the appropriate and effective dose of chromium supplement to assist in the rehabilitation process. Steps to carry out the research: 1- Survey and theoretical analysis of references and scientific researches related and similar to the subject of the study to collect and form the content of rehabilitation exercises and appropriate dose of chromium supplement.

2- Collecting data for the sample members in question. The personal data collection form included name, age, job, height, weight, club, degree of injury, date of injury.

Determine the appropriate dose of chromium supplement.

4- Designing the rehabilitation program.

5- Implementing the training program similar to the proposed performance. 6 - the use of a test to measure the efficiency of the biceps femoral muscles after recovery from partial muscle rupture. 


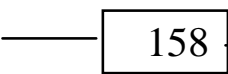

Statistical

- standard

$\bullet$

- Torsion

- Rate of improvement.

- Test (t).

Presentation, discussion and interpretation of results:

\section{Table (2)}

The significance of the differences between the mean of pre and post measurements for the experimental group In pain intensity variables $(\mathrm{N}=9)$

\begin{tabular}{|c|c|c|c|c|c|c|c|c|}
\hline \multirow[b]{2}{*}{ group } & \multirow[b]{2}{*}{ variable } & \multirow{2}{*}{$\begin{array}{c}\text { The } \\
\text { muscle }\end{array}$} & & & & & \multirow[b]{2}{*}{$\begin{array}{c}\text { Test } \\
\mathbf{t}\end{array}$} & \multirow[b]{2}{*}{ Sign } \\
\hline & & & Average & $\begin{array}{l}\text { Standard } \\
\text { deviation }\end{array}$ & Average & $\begin{array}{l}\text { Standard } \\
\text { deviation }\end{array}$ & & \\
\hline $\begin{array}{c}\begin{array}{c}\text { Experimental } \\
\text { group }\end{array} \\
\end{array}$ & \multirow{2}{*}{$\begin{array}{c}\text { Pain } \\
\text { intensity in } \\
\text { performance }\end{array}$} & \multirow{2}{*}{$\begin{array}{l}\text { biceps } \\
\text { femoral }\end{array}$} & 92 & 9.21 & 13 & 1.71 & 7.21 & Significant \\
\hline $\begin{array}{l}\text { Control } \\
\text { group }\end{array}$ & & & 89 & 8.41 & 17 & 2.01 & 6.55 & Significant \\
\hline
\end{tabular}

Value (t) (2.26) at the significance level (0.05)

Table (3)

The improvement rate of the affected muscle in the pain intensity variable for the experimental group In telemetry from tribalism

\begin{tabular}{|c|c|c|c|c|c|c|}
\hline \multirow[b]{2}{*}{ group } & \multirow[b]{2}{*}{ variable } & \multirow{2}{*}{ weeks } & $\overline{\text { pre }}$ & post & \multirow{2}{*}{$\begin{array}{c}\text { difference } \\
\text { between } \\
\text { the two } \\
\text { averages }\end{array}$} & \multirow{2}{*}{$\begin{array}{c}\text { Rate of } \\
\text { improvement } \%\end{array}$} \\
\hline & & & Average & Average & & \\
\hline \multirow{4}{*}{$\begin{array}{l}\text { Experimental } \\
\text { group }\end{array}$} & \multirow{4}{*}{$\begin{array}{c}\text { Pain } \\
\text { intensity in } \\
\text { performance }\end{array}$} & first & 92 & 73 & 9 & $2.65 \%$ \\
\hline & & second & 73 & 40 & 33 & $45.20 \%$ \\
\hline & & third & 40 & 25 & 18 & $37.75 \%$ \\
\hline & & fourth & 25 & 13 & 12 & $48.00 \%$ \\
\hline
\end{tabular}

Table (2) (3) shows that there are statistically significant differences between the pre and post measurement averages in the experimental group and the control group in favor of the experimental group and in favor of the post measurement in the muscular Pain intensity in performance variable in both the motion and numerator movement.

2 - View the results of muscle strength: 
Table (4)

The significance of the differences between the mean of pre and post measurements for the experimental group In thigh circumference variables $(\mathbf{N}=9)$

\begin{tabular}{|c|c|c|c|c|c|c|c|c|}
\hline \multirow[b]{2}{*}{ group } & \multirow[b]{2}{*}{ variable } & \multirow[b]{2}{*}{$\begin{array}{l}\text { The } \\
\text { muscle }\end{array}$} & \multicolumn{2}{|l|}{ pre } & \multicolumn{2}{|l|}{ post } & \multirow[b]{2}{*}{$\begin{array}{r}\text { Test } \\
t\end{array}$} & \multirow[b]{2}{*}{ Sign } \\
\hline & & & Average & $\begin{array}{l}\text { Standard } \\
\text { deviation }\end{array}$ & Average & $\begin{array}{l}\text { Standard } \\
\text { deviation }\end{array}$ & & \\
\hline $\begin{array}{l}\text { Experimental } \\
\text { group }\end{array}$ & \multirow{2}{*}{$\begin{array}{l}\text { Thigh } \\
\text { circumference }\end{array}$} & \multirow{2}{*}{$\begin{array}{l}\text { biceps } \\
\text { femoral }\end{array}$} & 43.66 & 1.64 & 46.15 & 2.11 & 2.79 & Significant \\
\hline $\begin{array}{l}\text { Control } \\
\text { group }\end{array}$ & & & 44.11 & 1.55 & 45.73 & 2.19 & 2.14 & Significant \\
\hline
\end{tabular}

Value (t) (2.26) at the significance level (0.05)

Table (5)

Percentage change in Thigh circumference for the experimental group Between average measurements before and after application of the program

\begin{tabular}{l|c|c|c|c|c|c}
\hline \hline \multirow{2}{*}{ group } & variable & \multirow{2}{*}{$\begin{array}{c}\text { The } \\
\text { muscle }\end{array}$} & Average & Average & $\begin{array}{c}\text { presterence } \\
\text { between } \\
\text { the two } \\
\text { averages }\end{array}$ & $\begin{array}{c}\text { Rate of } \\
\text { improvement \% }\end{array}$ \\
\hline \hline $\begin{array}{l}\text { Experimental } \\
\text { group }\end{array}$ & $\begin{array}{c}\text { Thigh } \\
\text { circumference }\end{array}$ & $\begin{array}{c}\text { biceps } \\
\text { femoral }\end{array}$ & 43.66 & 46.15 & 2.49 & $5.39 \%$ \\
\hline \hline
\end{tabular}

Table (4)(5) shows that there are statistically significant differences between the pre and post measurement averages in the experimental group and the control group in favor of the experimental group and in favor of the post measurement in the muscular Thigh circumference variable in both the motion and numerator movement

Table (6)

The significance of differences between the mean measurements before and after applying the program to the experimental group In muscle strength variables $(\mathrm{N}=9)$

\begin{tabular}{|c|c|c|c|c|c|c|c|c|}
\hline \multirow[b]{2}{*}{ group } & \multirow[b]{2}{*}{ variable } & \multirow[b]{2}{*}{$\begin{array}{c}\text { The } \\
\text { muscle }\end{array}$} & \multicolumn{2}{|c|}{ pre } & \multicolumn{2}{|c|}{ post } & \multirow[b]{2}{*}{ Test $t$} & \multirow[b]{2}{*}{ Sign } \\
\hline & & & Average & $\begin{array}{l}\text { Standard } \\
\text { deviation }\end{array}$ & Average & $\begin{array}{l}\text { Standard } \\
\text { deviation }\end{array}$ & & \\
\hline \multirow{2}{*}{$\begin{array}{l}\text { Experi } \\
\text { mental } \\
\text { group }\end{array}$} & \multirow{4}{*}{$\begin{array}{l}\text { Muscle } \\
\text { Strength }\end{array}$} & \multirow{4}{*}{$\begin{array}{l}\text { biceps } \\
\text { femoral }\end{array}$} & 28.75 & 4.13 & 36 & 3.97 & 3.79 & Significant \\
\hline & & & 41.22 & 2.89 & 47.5 & 2.14 & 5.27 & Significant \\
\hline \multirow{2}{*}{$\begin{array}{l}\text { Control } \\
\text { group }\end{array}$} & & & 28.11 & 3.98 & 34.8 & 3.94 & 3.48 & Significant \\
\hline & & & 39.40 & .3 .01 & 44.34 & 2.13 & 2.87 & Significant \\
\hline
\end{tabular}

Value (t) (2.26) at the significance level (0.05)

Assiut Journal For Sport Science Arts 
Table (4) shows that there are statistically significant differences between the pre and post measurement averages in the experimental group and the control group in

\section{Table (7)}

The percentage of improvement of the affected knee in the muscle strength variable for the experimental group in Dimensional measurements from tribalism

\begin{tabular}{|c|c|c|c|c|c|c|}
\hline \multirow[b]{2}{*}{ group } & \multirow[b]{2}{*}{ variable } & \multirow[b]{2}{*}{$\begin{array}{l}\text { Movement } \\
\text { type }\end{array}$} & pre & post & \multirow{2}{*}{$\begin{array}{l}\text { difference } \\
\text { between } \\
\text { the two } \\
\text { averages }\end{array}$} & \multirow[b]{2}{*}{$\begin{array}{c}\text { Rate of } \\
\text { improvement } \%\end{array}$} \\
\hline & & & Average & Average & & \\
\hline \multirow{2}{*}{$\begin{array}{l}\text { Experimental } \\
\text { group }\end{array}$} & \multirow{2}{*}{$\begin{array}{l}\text { Muscle } \\
\text { Strength }\end{array}$} & ontraction & 28.75 & 36 & 7.25 & $20.13 \%$ \\
\hline & & extend & 41.22 & 47.5 & 6.28 & $13.22 \%$ \\
\hline
\end{tabular}

In Table (7) there are statistically significant differences between the median of the pre and post measurements of the members of the research sample in muscular strength in favor of the median measurements of the experimental sample where the calculated $\mathrm{T}$ value was greater than its tabular value at the level of 0.05 , and the improvement rate was (20\%). .

Second: Discuss the results

It is clear from Table (2) that there are statistically significant differences between the pre- and postmeasurements of the members of the research sample in the mean measurements of the favor of the experimental group and in favor of the post measurement in the muscular force variable in both the motion and numerator movement. degree of pain, and they were all in favor of the telemetry, where the calculated value $(t)$ and for all measurements was greater than its tabular value at the level of 0.05 , as All improvement rates reflect positive improvement in favor of telemetry.

The researcher attributed this statistically significant improvement to the regularity of the research sample in dealing with the chromium supplement daily and the effectiveness of the performance of rehabilitation units exercises in addition to the diversity in the forms and methods of exercise, and not confined to one type or one 
method of exercise was between the help, free, against resistance, As well as the proper and progressive gradient, which is commensurate with the nature of the injury and diagnosis of doctors where the field was available for exercise throughout the program.

Sameh Amir El Sayed El Halabi (2015), 6 Mahmoud Mahmoud Mohamed Hozayen (2013), 12 shows the success of the rehabilitative exercises that have helped to relieve pain in sports women. Mohammed Qadri Bakri (2002) (11) stated that kinetic therapy is considered the basis of medical treatment, which derives its effect from the scientific uses of various natural elements for the treatment and rehabilitation of injuries and manifestations of fatigue and fatigue without these natural means of any side effects as in many Of abnormal chemical and radiological means. On the other hand, pain levels increase as a result of stress and acute response of the immune system that occurs as a result of infection. Trivalent chromium is an essential mineral that has been shown to reduce oxidative stress.

The study "Moonsie" (1993) (26) confirmed the chromium supplements led to an increase in the total immune globulin in the serum, which is to enhance the primary antibody response to red blood cells as a result of injury.

As for the role played by cetrol, since increased cortisol secretion, which has the potential to inhibit cytokines, Mowat et al. (1993) 27 and McCarty (1993) 24 show that chromium supplementation Significant decrease in blood cortisol, thus lower pain levels as a result of reduced levels of muscle strain. This fulfills the first hypothesis, which states that "there are statistically significant differences between the averages of pre- and postmeasurements in the (degree of pain) of the members of the research sample and in favor of the dimensions of the telemetric measurements." As shown in Table (4) (5) (6) (7) There were statistically significant differences between the pre- and postmeasurements of the members of the research sample in the mean measurements of (muscle 
strength), and they were all in favor of the telemetry, where the calculated $\mathrm{T}$ value and all measurements were greater than their tabular value at the level of 0.05 , and all the improvement rates to reflect the positive improvement In favor of telemetry.

The researcher attributed the obvious positive superiority of the members of the research sample in the ocean and the muscle strength of the affected muscle to the effectiveness of the group of rehabilitation exercises that were applied to them.

The study of "Sameh Amir El Sayed El Halabi" (2015) (6), "Mahmoud Ahmed Mohamed Hozin" (2013) (12) the success of rehabilitation exercises, which helped a lot to substantially improve the muscular strength of the injured muscles as they approached the same in the healthy limb, which was reflected on Muscle circumference.

These results are also consistent with what Mohammed Kadri Bakri (2000) 11 points out that integrated physical rehabilitation positively affects muscle strengthening, relaxing strained muscles, stimulating blood circulation, improving muscle tone, relieving pain and improving mental state.

On the other hand, insulin works to increase the absorption of muscle amino acid and build and synthesize protein and reduce protein degradation. The increase in the level of plasma glucose is the basis for reducing muscle damage and protein degradation, and pointed out, "Wang et, al," (2005) 33 Chromium works to improve and enhance insulin sensitivity. Anderson (2002) (15) explains that chromium increases the level of cellrelated insulin by activating the insulin receptor kinase, leading to increased insulin sensitivity. Evans, Bowman (1992) 17 reported that chromium can increase insulin absorption and significantly increase leucine absorption in skeletal muscle cells.

Ziegenfuss et al. (2017) (34) insulin plays an important role in muscle building and protein synthesis. Evans (1989) (18) and Kaats et al. (1998) 22 found that 
chromium supplementation increases body mass and crosssection area of muscles.

This fulfills the second hypothesis, which states that "there are statistically significant differences between the mean scores of the pre- and post-measurements in the muscle strength of the members of the research sample and in favor of the scores of the post-scales."

\section{Conclusions:}

1. Rehabilitation exercises lead to positive results for patients with partial rupture of the biceps femoral muscles to a marked improvement in both (the degree of pain and muscle strength).

2. The diversity in the methods of implementation of rehabilitation exercises and the gradual application in the case of each person is one of the factors that increase the effectiveness of rehabilitation exercises for people with partial rupture of the biceps femoral muscles.

3 . The use of different types of exercises or tools in a standardized way effective in improving the degree of pain and increase muscle strength.

4. The element chromium contributed relatively well to the complete tissue speed. 5. The dose of chromium supplement $200 \mathrm{~m} / \mathrm{g} /$ day for four weeks is an appropriate dose to have a positive effect to assist in rehabilitation

\section{Recommendations:}

In the light of the researcher's findings, the following recommendations may be made:

1- Guided by the program of rehabilitation exercises "under research" and circulated in the centers and treatment institutions and hospitals for cases of partial rupture of the biceps femoral muscles. 2- must teach the injured how to perform these exercises and alert them to do these exercises at home during the period of application and after the program.

3- attention to the use of more than one method during the implementation of the proposed exercises (with the help - free - against resistance) according to the situation of each patient. 4- interest in the work of similar studies to identify the positive impact of supplement chromium on other cases of injuries.

\section{References:}

First: Arabic References: 1- Abul-Ela Abdel Fattah, Ibrahim Shaalan:

"Physiology of Training in Football, Dar Al-Fikr Publishing, Cairo, 2002.

2- Ahmed Abdel-Aziz Abdel Nasser: "The Effect of a 
Proposed Rehabilitation Program on the Structural Structure of the Back Muscles with Cramp", Ph.D. Thesis, Faculty of Physical Education, Helwan University, 2010

3- Osama Riyad Mohamed: "Sports Medicine and Stadium Injuries", Dar Al-Fikr AlArabi, Cairo, 1998

4- Osama Riad Mohamed, Imam Hassan Al-Najmi: "Sports Medicine and Stadium Injuries", Book Center for Publishing, Cairo, 1999

5- Ashraf El-Desouky Shaalan: "A test of measuring the efficiency of the posterior thigh muscles after recovery from muscle rupture," Assiut Journal of Science and Arts of Physical Education, No. 22, vol. 2, March 2006.

6- Sameh Amir El Sayed ElHalabi: Physical program of physical education and health after surgery thigh neck fracture, Master Thesis, Department of Biological and Health Sports Sciences, Faculty of Physical Education for Boys, Alexandria University, 2015.

7- Mohamed Hassan Saleh Hassan: "Rehabilitation of abdominal muscle rupture injuries for athletes", Master
Thesis, Faculty of Physical Education, Alexandria University, 2009.

8- Mohamed Adel Roshdy: "The Science of Sports Injuries", Al-Maaref Establishment, Alexandria, 2003

9- Mohamed Adel Roshdy, Mohamed Gaber Baraka: Mechanism of Spinal Injury ", Facility knowledge, Alexandria, 1997.

\section{0- Mohamed Abdel Hamid}

Farrag: "Chemistry of Muscle Injury and Physical Effort of Athletes", Dar Al-Wafaa for Printing and Publishing, 2004.

\section{1- Mohamed Qadry Bakry:} sports rehabilitation and sports injuries and modern rehabilitation, the book Center for Publishing, Cairo, 2000.

\section{2- Mahmoud Ahmed Mohamed \\ Hozayen:}

Effectiveness of a physical and water rehabilitation program for patients with cross-ligament anterior knee after laparoscopic surgery "PhD Thesis, Faculty of Physical Education for Boys, Department of Sports Health Sciences, Helwan University, 2013.

\section{3- Mukhtar Salem}

Mohammed, "Injuries of Stadiums", Al-Marikh Publishing House, Riyadh, 1987. 
14- Mervat El Sayed Mohamed: "Problems of Sports Medicine", Radiology for Publishing, Alexandria, 1998

15- Anderson, R.A. Chromium in the prevention and control of diabetes. Diabetes Metab. 26, 22:27. (2000).

16- Aronson J.K. Meyler's Side Effects of Drugs (Sixteenth Edition). The International Encyclopedia of Adverse Drug Reactions and Interactions. 2016, Pages 282-285 17- Evans GW, Bowman TD. Chromium picolinate increases membrane fluidity and rate of insulin internalization. J Inorg Biochem. 1992;46:243-50.

Doi: 10.1016/0162-0134 (92) 80034-S.

18- Evans GW: The effect of chromium picolinate on insulin controlled parameters in humans. International Journal of Biosocial and Medical Research. 1989, 11: 163180.Google Scholar

19- Gilbert R.Kaats KennethBlum DennisPullin SamuelC.Keith RobertWood A randomized, double-masked, placebo-controlled study of the effects of chromium picolinate supplementation on body composition: A replication and extension of a previous study. Current Therapeutic Research. Volume 59, Issue 6, June 1998, Pages 379-388
20- Henry C. Lukaski, Ph.D.*, William A. Siders, Ph.D., and James G. Penland, Ph.D. Chromium picolinate supplementation in women: effects on body weight, composition, and iron status. Applied nutritional investigation, Nutrition 23 (2007) 187-195.

21- Hoffman NJ, Penque BA, Habegger KM, et al. Chromium enhances insulin responsiveness via ampk. J Nutr Biochem. 2014;25:56572. doi: 10.1016/j. jnutbio. 2014. 01.007.

22-Kaats GR, Blum K, Pullin D, et al. A randomized, double-blind, placebocontrolled study of the effects of chromium picolinate supplementation on body composition: A replication and extension study of a previous study. Curr Ther Res. 1998; 59:379-88. doi: 10.1016/ S0011-393X (98) 85040-6.

23-Kerger, B.D., Paustenbach, D.J., Corbett, G.E. and Finley, B.L. (1996) Absorption and elimination of trivalent and hexavalent chromium in humans following ingestion of a bolus dose in drinking water. Toxicol. Appl. Pharmacol. 141, 145^158.

24-McCarty MF. Homologous physiological effects of phenformin and chromium 
picolinate. Med Hypotheses 41:316-324, 1993

\section{5-Melvin H Williams.}

Dietary Supplements and Sports Performance: Minerals. Journal of the International Society of Sports Nutrition. June 2005, 2:43

26-Moonsie-Shageer

S,

Mowat DN. Effect of level of supplemental chromium on performance, serum constituents, and immune status of stressed feeder calves. J Anim Sci 71:232-238, 1993.

27-Mowat DN, Chang $X$, Yang WZ. Chelated chromium for stressed feeder calves. Can J Anim Sci 73:49-55, 1993

28-Roy, S., \& Irvin, R. Sports medicine:

Prevention, evaluation, management, and rehabilitation. Englewood Cliffs, N.J: Prentice-Hall. (1983).

29-Sahin K, Tuzcu M, Orhan $\mathrm{C}$, Gencoglu $\mathrm{H}$, Ulas $\mathrm{M}$, Atalay M, Sahin N, Hayirli A, Komorowski JR. The Effects of Chromium Picolinate and Chromium Histidinate Administration on $\mathrm{NF}-\kappa \mathrm{B}$ and Nrf2/HO-1 Pathway in the Brain of Diabetic Rats. Biol Trace Elem Res, 2012; 150(1-3):291-6.

30-Sundaram B, Singhal K, Sandhir R. Antiatherogenic effect of chromium picolinate in streptozotocin-induced experimental diabetes. J Diabetes, 2013; 5 (1):43-50.

31- US Environmental Protection Agency (1984) Health ejects assessment for hexavalent chromium. Prepared by the O/ce of Health and Environmental Assessment, Environmental Criteria, EPA/540/ 1-86-019 Cincinnati, updated 1998.

32-Walker LS , Bemben MG, Bemben DA, Knehans AW. Chromium picolinate effects on body composition and muscular performance in wrestlers. Med Sci Sports Exerc. 1998 Dec;30 (12): 1730-7.

33-Wang H, Kruszewski A, Brautigan DL. Cellular chromium enhances activation of insulin receptor kinase. Biochemistry. 2005;44: 8167-75. doi: 10.1021/ bi0473152. [PubMed]

[CrossRef] [Google Scholar] 34- Ziegenfuss, T. N. Lopez, H. L. Kedia, A. Habowski, S. M. Sandrock, J. E. Raub, B. Kerksick, C. M. and Ferrando A. A. Effects of an amylopectin and chromium complex on the anabolic response to a suboptimal dose of whey protein. J Int Soc Sports Nutr. 2017; 14: 6. 